\title{
Catholic Slaveowners and the Development of Georgetown University's Slave Hiring System, 1792-1862
}

\author{
Elsa Barraza Mendoza \\ Georgetown University, Washington, DC, USA \\ eb939@georgetown.edu
}

\begin{abstract}
This article examines the place of enslaved laborers in the founding and operations of Georgetown University. It draws evidence from the school's administrative and financial records; the archives of the Maryland Province of the Society of Jesus; and manuscript collections in Maryland and Washington, DC. The school generally rented rather than bought and owned enslaved people to work on campus. The school used its position as a provider of education and religious services to obtain enslaved laborers from two types of Catholic slaveowners: priests and parents-women in particularwho sent their children to Georgetown. Enslaved laborers worked at the school from its earliest days until the abolition of slavery in Washington, DC, in 1862. Indeed, the school's last enslaved worker, Aaron Edmonson, left campus in March of 1862, only a month before the passage of the Compensated Emancipation Act of the District of Columbia.
\end{abstract}

\section{Keywords}

schools and colleges - Washington, DC - Maryland Province - Georgetown University enslaved people - enslaved labor - hiring of enslaved people - women as slaveowners

In January 1792, Thomas Corcoran (1754-1830), a prominent merchant with a storefront in Georgetown, received an order for eight pairs of shoes from the newly founded Georgetown College. Among the recipients of these pairs of shoes made or resoled by Corcoran were William Gaston (1778-1844), the 
first student enrolled at the college; Jean Edouard de Mondésir (1770-1844), a Sulpician seminarian recently emigrated from France and Georgetown College's first teacher; Francis Neale (1756-1837), a secular priest from the diocese of Baltimore; and four enslaved people who labored and most probably resided on campus: Byrne, Suckey, Joseph, and Nat. ${ }^{1}$ Since beginning operations in 1792, Georgetown College owned or hired enslaved people to work on campus in areas such as the kitchen, the classrooms, the refectory, the infirmary, and the gardens. ${ }^{2}$

This article examines the place of enslaved laborers in the founding and operations of the university and its community. Through research in the university's administrative and financial records; the archives of the Maryland Province of the Society of Jesus; and manuscript collections in Maryland and Washington, DC, it proposes three key arguments: first, the school used its position as a provider of education and religious services to obtain enslaved laborers from two types of Catholic slaveowners: priests and parents-women in particular - who sent their children to Georgetown. Second, the school itself never owned many individuals, favoring renting laborers over owning them. Georgetown did not own more than five people in any given year from 1792 to 1862. Finally, the school's dependence on enslaved labor was not mitigated by the Jesuit order's sale of 272 people from its plantations in 1838 . Indeed, the last enslaved man left campus in March of 1862, only a month before the passage of the Compensated Emancipation Act of the District of Columbia.

Georgetown University's written histories are silent on Byrne, Joseph, Nat, and Suckey, and the many others whose names are lost to us. But enslaved laborers kept the school operating for decades. Slavery as an economic force

1 Thanks to Fr. David J. Collins, S.J., Adam Rothman, and the JJS editors for their feedback. The research for this article owes much to Lynn Conway, Mary Beth Corrigan, the rest of the staff at the Booth Family Center for Special Collections at Georgetown University, and fellow Georgetown Slavery Archive collaborators Julia Bernier and Cory Young. Ledger A1 [henceforth LA1], 1789-1793 (I.A.1.a), Georgetown College Financial Records: Vault Collection, Georgetown University Archives [henceforth GUA], Booth Family Center for Special Collections, Georgetown University. The Journal of Jesuit Studies requires biographical dates for all historical figures, but the birth and death dates for most of the enslaved people named in this article are unknown and cannot be included. This is itself a lingering effect of slavery.

2 Georgetown University was founded in 1789, the year when Bishop John Carroll (1735-1815), a former Jesuit, acquired the deed for the school's land. Classes began on January 2, 1792. See Robert Emmet Curran, The Bicentennial History of Georgetown University (Washington, DC: Georgetown University Press, 1993), 1:23-24, here 34. For examples of activities of enslaved people on campus during its first years, see Ledger A3 [henceforth LA3], 1796-1799 (I.A.i.c), GUA; Journal C [henceforth JC], (I.A..2.a) 1808-1813; GUA; Journal D [henceforth JD], 18131821 (I.A.2.b), GUA; Infirmary Ledger [henceforth IL], 1816-1830, Box 1, Folder 1, Infirmary Collection, [henceforth IC], GUA. 
that dominated the republic is invisible in interpretations that sought to create a wide-ranging account of the life and growth of the US's first Catholic university. The main characters of Georgetown's histories are archbishops, Jesuits, and prominent people. In accounts informed by archival work in the Jesuit Roman Archives (ARSI), slavery appears only in observations such as that students "even used slaves to pay for tuition," or that "there were never more than a few slaves at Georgetown college."3 As a result, the slaveholding that was crucial to the neighborhood, city, and region in which Georgetown found itself appears irrelevant to the school's existence. Nothing could be further from the case.

Local archives-such as the school's own financial and academic records-offer a different perspective than the bureaucratic exchanges with Rome. Here we find how enslaved people were essential to the school's daily operations. Men and women held in slavery cooked and cleaned for the school. They did the laundry and worked the farm. They even cared for the sick, including on at least one occasion the school's president and treasurer. The profits from their sale gave a financial lifeline to the school. ${ }^{4}$ Men and women leased to Georgetown by Catholic slaveowners appear in balance sheets that span multiple financial ledgers. The occupations of some of them, as well as significant events in their lives, can be traced in cashbook and daybook entries, along with transactions for whiskey, sugar, and meat. Their ceaseless presence is a testament of slavery's grip on college life.

This dependence on enslaved laborers was widespread in American colleges. As historian Craig Steven Wilder argues, "it was the violent expansion and integration of the Atlantic slave economies that created the financial and social conditions for the growth of higher education."5 The Chesapeake was full of religious, educational, and lay institutions with significant entanglements

3 Curran, Bicentennial History; Joseph Thomas Durkin, Georgetown University: The Middle Years, 1840-1900 (Washington, DC: Georgetown University Press, 1963); Durkin, Georgetown University, First in the Nation's Capital (Garden City, NY: Doubleday, 1964). On the use of enslaved people for tuition payments and the presence of enslaved laborers see Curran, Bicentennial History, $36 ; 361 n 27$.

4 191A Ledger [henceforth 191AL], Box 68, Addenda to the Maryland Province Archives [henceforth AMPA], Booth Family Center for Special Collections, Georgetown University; Washington Lots, House Ledger [henceforth WLHL], 1846-1862 (I.AA.i.f), GUA; Journal G [henceforth JG], 1838-1873 (I.A.2.e.), GUA; Various Accounts, Students, Workmen, Societies [henceforth VASWS], 1837-1846 (I.AA.1.h.) GUA; Ledger F [henceforth LF], 1838-1842 (I.A.1.h.), GUA.

5 Craig Steven Wilder, "War and Priests: Catholic Colleges and Slavery in the Age of Revolutions," in Slavery's Capitalism: A New History of American Economic Development, ed. Sven Beckert and Seth Rockman (Philadelphia: University of Pennsylvania Press, 2016), 227-42, here $231-32$. 
to slaveholding. As Jennifer Oast has shown in her study of universities and slaveholding churches in Virginia, institutions of higher education were prolific owners or hirers of enslaved people. ${ }^{6}$ Thus, Georgetown's entanglement with slaveholding can be examined as a microcosm of the rampant exploitation that spread across the nation. Its practices of hiring enslaved people are an example of how leasing people allowed for the persistence of slavery in cities, and Georgetown's use of enslaved laborers is a reflection of how Catholic education depended on the enslavement of others.

Two factors defined Georgetown's relationship with slavery: its location and its ties to the Roman Catholic Church. The practice of hiring enslaved people thrived in many southern cities and Georgetown was no exception. ${ }^{7}$ The city possessed a thriving enslaved people market. ${ }^{8}$ In the 179 os, the first decade of the college's operation, around twenty-eight percent of the city's population were enslaved people. ${ }^{9}$ Among the first families with children enrolled in the college, seventy percent owned at least one person. In short, the culture of slavery on campus mirrored that flourishing right outside its gates.

The American Catholic Church was at the heart of Georgetown's reliance on enslaved labor. After the suppression of the Society of Jesus in 1773, Maryland's twenty-one Jesuits - the region's only Catholic priests—organized with the purpose of governing their religious affairs and "preserving in the same hands the property of the Houses of the Society."10 This attempt at episcopal

6 Jennifer Oast, Institutional Slavery: Slaveholding Churches, Schools, Colleges, and Businesses in Virginia, 1680-1860 (New York: Cambridge University Press, 2016).

7 Kathleen Menzie Lesko, Valerie Babb, and Carroll R. Gibbs, Black Georgetown Remembered: A History of Its Black Community from the Founding of the Town of George in 1751 to the Present (Washington, DC: Georgetown University Press, 1991), 2-3; Chris Myers Asch and George Derek Musgrove, Chocolate City: A History of Race and Democracy in the Nation's Capital (Chapel Hill: The University of North Carolina Press, 2017), 39-46; MaryBeth Corrigan, "Imaginary Cruelties?: A History of the Slave Trade in Washington D.C.," Washington History 12, no. 2 (Fall/Winter 2001-2): 4-27, here 6; Jonathan D. Martin, Divided Mastery: Slave Hiring in the American South (Cambridge: Harvard University Press), 161-63.

8 See Lesko, Babb, and Gibbs, Black Georgetown Remembered, 2-3; David Mould and Missy Loewe, Remembering Georgetown: A History of the Lost Port City (Charleston, SC: The History Press, 2009), 30- 32 .

9 Lesko, Babb, and Gibbs, Black Georgetown Remembered, 2, 6.

10 "John Carroll's plan for organizing the mission," Box 2, Folder 2, Maryland Province Archives [henceforth MPA], Booth Family Center for Special Collections, Georgetown University. On 
governance produced two results: Georgetown College and the Corporation of Roman Catholic Clergymen (henceforth CRCC). Founded in 1792, the corporation consolidated many of the properties that the Jesuits had controlled in the Maryland colony but had lost upon the suppression. Among its properties numbered about 323 people on nine plantations, encompassing about thirteen thousand acres across Maryland. ${ }^{11}$ Georgetown's founders and several members of its board of directors were stakeholders in this organization that held their assets in a trust. ${ }^{12}$

The priests who founded Georgetown and the corporation were also individual owners of properties, which in many cases included enslaved people. ${ }^{13}$ While not every priest left a record of his attitudes toward slavery, many did, and these indicate no moral qualms with human ownership. ${ }^{14}$ Georgetown's founders were known as slavers. They were even accused of trafficking enslaved people by two

the Maryland Jesuits' organization after the suppression, see Ronald A. Binzley, “Ganganelli's Disaffected Children: The Ex-Jesuits and the Shaping of Early American Catholicism, 1773-179o," U.S. Catholic Historian 26, no. 2, Catholics in the Colony of Maryland and the Early Republic (Spring 2008): 44-77, here 59; Robert Emmet Curran, "Ambrose Maréchal, the Jesuits, and the Demise of Ecclesial Republicanism in Maryland, 1818-1838," in Shaping American Catholicism: Maryland and New York, 1805-1915, ed. Curran (Washington, DC: Catholic University of America Press, 2012), 13-29, here 14-16; Catherine O’Donnell, "John Carroll and the Origins of an American Catholic Church, 1783-1815," William and Mary Quarterly 68, no. 1 (January 2011): 101-26.

11 During the suppression of the Society of Jesus, the former Jesuits did not write reports on the state of their property. The number of people is an estimate done by reviewing the number of people enslaved on each estate according to the 1790 Federal Census. For their properties, see Liber JC, No. 3, fol. 285, General Court Land Record Books for the Western Shore of Maryland, "Properties," Box 23, Folder 14, MPA; "List of properties," Box 23, Folder 9, MPA.

12 Not every clergyman who taught at Georgetown was a member of the CRCC. For membership regulations, see "Membership in the Select Body of the Clergy, 1793 (1816)," in Thomas Hughes, History of the Society of Jesus in North America: Colonial and Federal (Documents), Volume 1, Part 2 (London: Longmans, Green, and Co., 1908), 1:768-69.

13 Proceedings of the General Chapter, October 11, 1784, Box 2, Folder 5, MPA; John Ashton, "On his personal property at the White Marsh," Box 35, Folder 6, MPA; Valuation of John Ashton's Negroes, Box 35, Folder 6, MPA; Will of Charles Sewall, Box 25, Folder 12, MPA; Will of Notley Young Box 25, Folder 8, MPA, Will of John Ashton, Box 25, Folder 9, MPA.

14 Eighteenth-century sermons from the Maryland mission reflect some of their attitudes toward slavery. Fr. John Boone $\left(1735^{-85}\right)$ thought slavery was an instrument to teach Christianity and implored masters to teach enslaved people to be good Christians, since their time "would be made up [...] in interest, by the interest with which they would learn to labor for your service." See Boone, "Medius vestrum stetit, quem vos nescitis. St. John. c.l. v.25 There stands (or: stood) one among you, whom you know not--“[1,26]" ACSC, Box 2, Folder 32; John Lewis (1720-88), the superior of the Maryland mission, in a sermon at Annapolis, described slavery as a vehicle for Christianization, “Tu quis es/Who art thou?” St. Jo.1.19, ACSC Box 4, Folder 32. 
Dominican priests who visited from Europe in $1813 .{ }^{15}$ Slaveholding enhanced their social status and provided revenues to their education mission. ${ }^{16}$ The school's founders had a contentious relationship with those they enslaved. At least twenty people sued members of the CRCC for their freedom on the basis that they were illegally enslaved. The priests involved in these suits were a member of Georgetown's initial board of directors and a future president of the school. ${ }^{17}$

The choice of using enslaved laborers at Georgetown College was an extension of Catholic slaveholding in Maryland. Catholic farmers, including Jesuit priests, were indistinguishable from their Protestant neighbors in using enslaved laborers in their plantations after the arrival of the first enslaved Africans in Maryland in 1642. ${ }^{18}$ Before the suppression of the Jesuits, priests enslaved men and women in their plantations and their first schools. However, Maryland's clergy counted on the generosity of the lay elite to provide them with enslaved laborers through gifts and bequests, and thereby had little initial need to visit the markets for plantation laborers. ${ }^{19}$ After the foundation of Georgetown College, there was no significant exchange of enslaved laborers between these plantations and

15 Robert Emmett Curran, "Rome, the American Church, and Slavery," in Curran, Shaping American Catholicism, 92-110, here 96-100.

16 Thomas Murphy, Jesuit Slaveholding in Maryland, 1717-1838 (New York, NY: Routledge, 2001), 26-30; Edward F. Beckett, "Listening to Our History: Inculturation and Jesuit Slaveholding," Studies in the Spirituality of Jesuits 28, no. 5 (1996): 1-48, here 6-9.

17 Members of the Queen and Mahoney Families sued John Ashton, Francis Neale, and Sylvester Boarman for their freedom. Their claim for freedom was that they descended from a free woman. In Maryland, slavery followed partus sequitur ventrem, where the status of children followed that of their mother. See Eric Robert Papenfuse, "From Recompense to Revolution: Mahoney v. Ashton and the Transfiguration of Maryland Culture, 1791-1802," Slavery \& Abolition: A Journal of Slave and Post-Slave Studies 15, no. 3 (1994): 38-62, here 38-47; Will G. Thomas III, "The Timing of Queen v. Hepburn: An Exploration of African American Networks in the Early Republic," O Say Can You See: Early Washington D.C., Law \& Family, http://earlywashingtondc.org/stories/queen_v_hepburn (accessed May 30, 2020). John Ashton was one of the first directors of Georgetown College and Francis Neale was president of the college 1808-9 and 1809-12.

18 The oldest record of Jesuit slaveholding in Maryland dates from 1717. For the Jesuits' turn to slavery, see Murphy, Jesuit Slaveholding, 3-33.

19 From 1717 until 1773, the Jesuits of Maryland received in bequest at the very least fifty-two enslaved people through the legacies of Catholic planters such as James Carroll, who left the Jesuits more than 2,500 acres of land and at least thirty people. On Carroll's bequest and his properties, see "White Marsh: Devise of James Carroll," in Hughes, History of the Society of Jesus in North America 1:248-50; "Codicil to James Carroll's Will, February 17, 1728," in Hughes, History of the Society of Jesus in North America, 1:250-51; Murphy, Jesuit Slaveholding in Maryland, 16, 35; and Charles Flannagan, "The Sweets of Independence: A Reading of the 'James Carroll Daybook, 1714-21"' (PhD diss., University of Maryland, 2005). 
the school. ${ }^{20}$ In fact, as labor became increasingly necessary on the campus, the college's leadership turned not to ownership but to renting people.

Leasing enslaved laborers - with the proceeds of their salaries benefiting their owners - was typical for the region. In the Chesapeake, the market to hire enslaved people was competitive. The region's economy depended on hiring to satisfy the temporal needs of its planters, manufacturers, and households. ${ }^{21}$ Hiring gave enslavers flexibility, steady revenues, and it allowed them to meet changing labor demands. ${ }^{22}$ This system suited the needs of an urban environment, where households and businesses did not require the same labor to operate as plantations. ${ }^{23}$

At Georgetown, economy and the priests' conceptions of manual labor guided the hire of enslaved people. Under the circumstances envisioned by the founder of the Jesuits, Ignatius of Loyola (c.1491-1556), Jesuit fathers formed to be engaged in apostolic activities would not be distracted by practical labors. These priests would dedicate themselves to missionary tasks and would only engage in manual work "when there [were] no others who do the work." 24 Thus, within the order it was foreseen that the "lowly and humble positions" such as "cook, steward, buyer, doorkeeper, infirmarian, launderer, gardener, and alms gatherer" 25 would be the responsibility of lay brothers within the order, who were not ordained priests. ${ }^{26}$ However, from 1758 to 1809 , the Maryland mission had no lay brothers. ${ }^{27}$ Thus enslaved laborers worked in plantations, clergy's households, and schools. ${ }^{28}$

20 St. Inigoes accounts, kept by Fr. Francis Neale, 1805-1808, Box 43, folder 3, MPA; Neale to Joseph Marshall, December 1, 1817, Box 26, Folder 2, MPA; DB [henceforth DB], 1812-1814 (I.A.4.d), GUA; DB, 1814-1817 (I.A.4.e), GUA.

21 Martin, Divided Mastery, 27-28; Peter Way, Common Labor: Workers and the Digging of North American Canals, 1780-1860 (New York: Cambridge University Press, 1993), 25-34; Barbara Jeanne Fields, Slavery and Freedom on the Middle Ground: Maryland During the Nineteenth Century (New Haven, CT: Yale University Press, 1984), 5, 27-28.

Martin, Divided Mastery, 165-94; John J. Zaborney, Slaves for Hire: Renting Enslaved Laborers in Antebellum Virginia (Baton Rouge: Louisiana State University Press, 2012), 10-27.

23 Richard C. Wade, Slavery in the Cities: The South 1820-1860 (New York: Oxford University Press, 1964), 21; Midori Takagi, "Rearing Wolves to our Own Destruction:" Slavery in Richmond, Virginia, 1782-1865 (Charlottesville: University Press of Virginia, 1999).

24 Ignatius of Loyola, The Constitutions of the Society of Jesus, trans. George E. Ganns (St. Louis, MO: Institute of Jesuit Sources, 1970), 433 [henceforth Constitutions].

25 Constitutions, 148.

26 Constitutions, 13, 148, 305 .

27 Catalog of Members of the Maryland Mission of the Society of Jesus, 1634-1806 (Woodstock, MD: Ex Typis Collegii Ss. Cordis, 1887); Catalogus Sociorum Missionis Federatae Societatis Jesu, 1807 (Woodstock, MD: Ex Typis Collegii Ss. Cordis, 1887).

28 Authors have overlooked the connection between the number of lay brothers and the use of enslaved laborers. See Murphy, Jesuit Slaveholding, 3-32, 129-35; Beckett, "Listening to Our 
The school's founders had privileged access to the labor of enslaved people. Hiring enslaved people for the members of the CRCC was not a business arranged at the market or through correspondence with strangers, as was common in the region. Instead, it was part of parish business since the early years of Maryland's Catholic Church. ${ }^{29}$ Professors, parents of students, and women leased out enslaved laborers to Georgetown college. Beyond its economic benefits, hiring enslaved people was a social practice that connected the school's leaders to a community. It was the basis for the school's labor system, and a means that made both the expansion of Catholic education and Catholicism itself possible.

\section{2 \\ The Hire of Enslaved People during Georgetown's First Decades, 1792-1814}

During Georgetown's first three decades, the school hired up to twelve enslaved people per year to work in crucial activities for its construction, maintenance, and operation. ${ }^{30}$ Every level of the school's administration profited from enslaved laborers. For example, a lay professor, Charles Boarman (1715-1819), rented four enslaved people on a yearly basis: Lewis, Sam, Polly, and Sucky. He also rented two enslaved carpenters for the expansion of one of the college's buildings. Boarman used the funds he received for their labor to finance the education of his two children enrolled at the school. ${ }^{31}$

History," $5^{-11}$. Maryland's use of enslaved laborers was similar to other Jesuit missions in the Atlantic, such as sixteenth-century Brazil. The Jesuit superior there, Manuel da Nóbrega (1517-70), declared that the Jesuits could not "live without some slaves to hew wood and draw water and bake our daily bread and perform other duties that cannot be carried out by lay brothers since they are so scarce." See Manuel da Nóbrega to Simão Rodriques, August 9, 1549, cited in Alida C. Metcalf, Go-Betweens and the Colonization of Brazil: 1500-16oo (Austin: University of Texas Press, 2005), 180.

29 George Hunter's book for memoranda 1770-1785 172d, Box 46, Folder 6, MPA; St. Thomas Account Book, Box 47, Folder 2; St. Thomas Manor Account book, Box 46, Folder 6, MPA. On region's hiring practices, see Martin, Divided Mastery, 85; Zaborney, Slaves for Hire, 98-102.

30 DB, 1814-1817 (I.A.4.e), GUA; IL, 1816-1830, Box 1, Folder 1, IC, GUA; "Fr. Ripetti's Notes on the History of Gervase," Old Archives-Buildings, Box 3, Folder 4, GUA; Ledger C [henceforth LC], 1803-1813 (I.A.i.e), GUA; Robert Molyneux to Charles Neale, October 1st, 1806, Box 93, Folder 2, MPA; LA3, 1796-1799 (I.A.i.c), GUA; JC (I.A..2.a) 1808-1813, GUA, JD, 1813-1821 (I.A.2.b), GUA.

31 Ledger B1 [henceforth LB1], 1800-1803 (I.A.i.d), GUA; LC, 1803-1813 (I.A.i.e.), GUA; JC, 18081813 (I.A.2.a.), GUA; JC, 1808-1813 (I.A.2.a.), GUA; DBLC, 1803-1808 (I.A.A.i.b), GUA; Expense Book [henceforth EB], 1802-1808 (I.A.3.b), GUA; IL, 1816-1830, Box 1, Folder 1, IC, GUA. This Sucky should not be confused with the Suckey enslaved by Leonard Neale. 
The school's religious authorities also profited from the people they enslaved. Leonard Neale leased the school to eight people between 1792 and 1802, during his tenure as coadjutor bishop of Baltimore (1795-1815) and president of Georgetown (1799-1806). Regis, George, Suckey, Stashy, Jenny, Nace, John, and Jack were brought by Neale from Prince George's County to the city of Georgetown. ${ }^{32}$ Neale received on average $\$ 16$ for each of them on his accounts. ${ }^{33}$ Neale's brother, Francis, a professor and the college's fourth president (in office 1809-12), also hired out two people to the institution, Henrietta Edelen and an unnamed man. Edelen labored at the washhouse while Francis Neale resided at the college as convener of the residence. ${ }^{34}$

Diocesan priests were not the only clergymen who participated in the slave trade at Georgetown. From 1796 to 1799 , members of the Society of the Priests of Saint Sulpice, commonly known as Sulpicians, held the offices of president, vice-president, and multiple professorships at the school. ${ }^{35}$ These priests arrived in the United States after fleeing the French and Haitian revolutions. Their presence at Georgetown was integral to the school's slave hiring system. The Sulpicians connected Georgetown to slave hiring markets within Maryland's French community. ${ }^{36}$ During their years on campus, creole students paid servant attendance fees and used enslaved people to pay school costs. A Sulpician priest kept an enslaved woman born in Santo Domingo on campus, other Sulpicians used enslaved men to carry their bags, and a widowed

32 "Leonard Neale, Certificate of Slaves," March 2, 1802, Liber H. No. 8, 1802, RG 351, NARA-DC.

33 LA1, 1789-1793 (I.A.1.a), GUA; JC, 1808-1813 (I.A.2.a), GUA; LA3, 1796-1799 (I.A.i.c.), GUA; LB1, 1800-1803 (I.A.i.d.), GUA; LC, 1803-1813 (I.a.I.e), GUA; DBLC, 1803-Nov. 1808 (I.A.A.1.b.), GUA; DB, 1809-1812 (I.A.4.c.), GUA.

34 F. Neale, Cash Book, 1818-1823 (I.A.3.e.), GUA; Catalogus Sociorum Missionis Federatae Societatis Jesu, 1818 (Woodstock, MD: Typis Collegii Ss. Cordis, 1893) 3. Before Henrietta Edelen, the Neales hired out an unnamed woman to Georgetown's washhouse. See EB, 17941802 (I.A.3.a.), GUA.

35 The Sulpicians were invited by Bishop John Carroll to lead Georgetown University and to build a seminary in Baltimore. Their presence at the college was a magnet for students from the West Indies who were fleeing the French Revolution, until the Sulpicians left in 1799. See John Carroll to Lord Arundell, October 4, 179o, Box 3, Folder 6, MPA; R. Nagot to the CRCC, August 22, 1799, Box 23, Folder 9, MPA; George M. Barringer, "They Came to Georgetown: The French Sulpicians," Georgetown Today (July 1977): 7-8; Curran, Bicentennial History, 47-51; Kyle Roberts and Stephen R. Schloesser, eds., Crossings and Dwellings: Restored Jesuits, Women Religious, American Experience, 1814-2014 (Leiden: Brill, 2017), 381-84.

36 For the relationship between Sulpicians and creoles in Maryland, see Annabelle M. Melville, Louis Dubourg: Bishop of Louisiana and the Floridas, Bishop of Montauban, and Archbishop of Besancon, 1766-1833 (Chicago, IL: Loyola Press, 1986), 1:42; Peter Condon, "The Church in the Island of San Domingo," United States Catholic Historical Society: Historical Records and Studies XIII (May 1919): 11-61, here 36. 
woman who fled the Haitian revolution resided at Georgetown hiring out people she enslaved to the school. ${ }^{37}$ This eclectic group of emigrés leased at least seven people in their three years at the school. Their names were Maria Louisa, Joseph, Nicholas, Zeelam, Isely, Desiré, and an unnamed child. Isely passed away at Georgetown. The rest disappeared from the school records after the Sulpicians left in $1799 .^{38}$

After the Sulpicians' departure, the numbers of students from the West Indies decreased..$^{39}$ However, the practice of using enslaved labor to defray school costs did not end. Slave hiring to finance education expenses was a prevalent practice among Maryland families as well. ${ }^{40}$ These families often liquidated their outstanding debts with Georgetown using goods such as coffee, muscovado sugar, red wine, meat, lambs, horses, and Louisiana cotton, along with the labor of enslaved people. ${ }^{41}$ Thus, Georgetown's slaveholding system became tied to Maryland's Catholic community-who became the majority of its students - and its main source for enslaved laborers.

The hire of enslaved laborers did not prevent the school from purchasing and selling people. In a span of three decades, Georgetown sold a woman named Liddy to a lay man and purchased five people: George, David, Len, Wat, and an unnamed woman. In 1801, the college acquired a man named George from John Llewellin, a student indebted to the college.

37 On student fees, see LA3, 1796-1799 (I.A.i.c.), GUA; LB1, 1800-1803 (I.A.i.d) GUA. For the Sulpicians' use of enslaved laborers, see Students Sundry Accounts [henceforth SSA], (I.I.A.A.i. a), 1796-1798, GUA; LB1, 180o-1803 (I.A.i.d.), GUA. For women slaveowners, see LA3, 1796-1799 (I.A.i.c.), GUA; Book of Expenses and Remittances [henceforth BER], 17961799 (I.A.4.a), GUA.

38 For their names, see LA3, 1796-1799 (I.A.i.c.), GUA; LB1, 1800-1803 (I.A.i.d); SSA, (I.A.A.i.a), 1796-1798, GUA; DB 1798 (I.A.4.b); GUA; BER, 1796-1799 (I.A.4.a), GUA; Certificates of Freedom, 1806-1851, C29o-1, Baltimore County Court, Maryland State Archives.

39 The Sulpicians departed Georgetown after conflicts with the CRCC over revenues from the slave trade at Bohemia plantation. See John Carroll to Charles Plowden, July 7, 1797, John Carroll Papers, 2:218; John Carroll to Charles Plowden, December 11, 1798, John Carroll Papers, 2:248; Proceedings of the CRCC, December 3, 1798, Box 24, Folder 1, MPA; Proceedings of the Crcc, September 4, 1797, Box 24, Folder 1, MPA; Proceedings of the Crcc, October 9, 1799, Box 23, Folder 10, MPA; Curran, Bicentennial History, 50-52, 56; Thomas R. Ulshafer, "Slavery and the Early Sulpician Community in Maryland," U.S. Catholic Historian 37, no. 2 (Spring 2019): 1-21, here 14-15.

40 Curran, Bicentennial History, 36.

41 LA1, 1789-1793 (I.A.1.a), GUA; Ledger A2, 1793-1796, GUA; LA3, 1796-1799 (I.A.i.c.), GUA; LB1, 1800-1803 (I.A.i.d), GUA; LC, 1803-1813 (I.A.i.e), GUA. Curran makes a note of this process but does not explain how often families used enslaved people to pay their debts. See Curran, Bicentennial History, 36 . 
Georgetown credited Llewellin's account with $\$ 67$, which was more than one year of board. ${ }^{42}$ Another transaction between Georgetown and its lay community was the 1810 sale of Liddy to Phillip Bussard for $\$ 220$. For this sale Georgetown received $\$ 70$, one barrel of whiskey, and sugar. ${ }^{43}$ However, most of Georgetown's forays in the slave trade involved the CRCC. In 1802, Leonard Neale purchased the aforementioned Wat for \$40o. Afterwards, Neale sold him to St. Inigoes plantation-one of the estates of the corporation-with a profit for the college. ${ }^{44}$ Six years later, Francis Neale purchased a woman "for the use of the college," and a man named Len from the same plantation. ${ }^{45}$ From the White Marsh plantation, Georgetown's clergymen purchased David for $\$ 707$, although after a dispute they only paid $\$ 500$ to that estate. ${ }^{46}$

These transactions occurred in spite of a regulation from the CRCC that banned the "sale of slaves for life."47 In practice, Georgetown's priests saw people as capital. Transactions involving them were one of their preferred modes of payment for settling debts. Even after the corporation decided in 1813 to "dispose of the whole or greatest part of the slaves on their estates, for a term of years, after which they should be entitled to freedom," the priests at Georgetown kept hiring and using enslaved people on campus and their plantations. Enslaved people were fundamental to their finances, and they admitted at much. In 1820, for example, the CRCC repealed their decision to sell the people enslaved at their plantations, as they "on mature reflection considered the measure prejudicial."48 The discussions concerning this repeal are a mystery to us. However, it is not a secret that enslaved people were integral to Georgetown's growth during its first decades.

\footnotetext{
42 LB1, 1800-1803 (I.A.i.d), GUA

43 JC, 1805-1813 (I.A..2.a), GUA; LC, 1803-1813 (I.A.i.e.), GUA.

44 "Bill of Sale," Georgetown College Financial Records Vault Collection (unbound), Box 1; EB, 1802-1808 (I.A.3.b.), GUA; Agent's Cashbook 1802-1820, Box 69, AMPA.

45 LC, 1803-1813 (I.A.i.e), GUA; DBLC, 1803-1808 (I.AA.i.b), GUA. These transactions from 1808 are possibly related to the policy of the CRCC to identify supernumerary enslaved people to "dispose of them to good and Christian masters." See "Proceedings of the CrCc, May 12, 1808," Box 24, Folder 1, MPA.

46 DB, 1818-1821 (I.A.4.f), GUA.

47 Carroll to Francis Neale, October 3, 1815, Box 57.5, File 15, MPA; "Proceedings of the CRCC, May 18-19, 1813," Box 24, Folder 1, MPA.

48 "Proceedings of the CRCC, May 18-19, 1813," Box 24, Folder 1, MPA; "Proceedings of the CRCC, September 14, 1813," Box 24, Folder 1, MPA; "Proceedings of the CRCC, June 14, 1814," Box 24, Folder 1, MPA; "Proceedings of the CrCC, August 22, 1820," Box 24, Folder 1, MPA.
} 


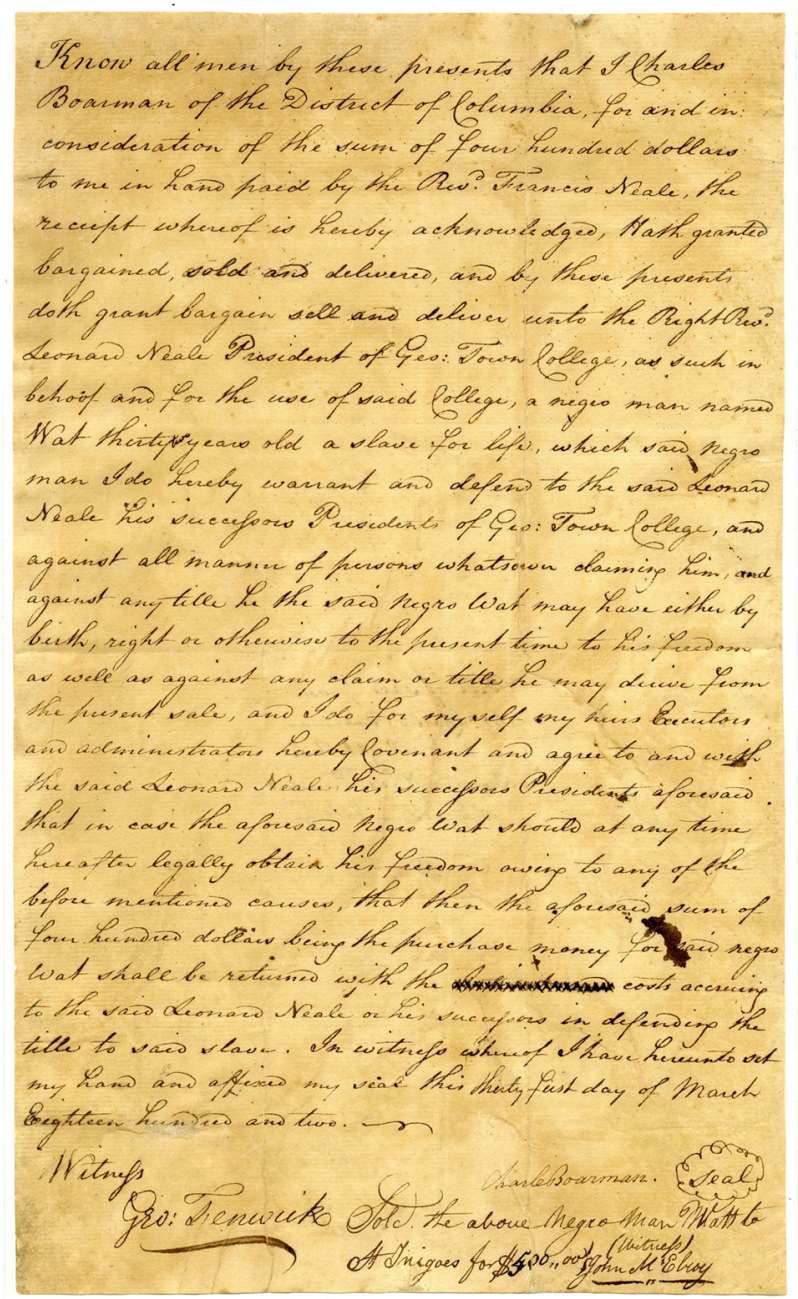

IMAGE 4.1

Bill of sale for a man named Wat purchased by the Rev. Leonard Neale, president of Georgetown College, in 1802 . GEORGETOWN UNIVERSITY ARCHIVES, WASHINGTON DC

Under the fully restored Jesuit order, the university and its dependence on enslaved labor did not change. ${ }^{49}$ However, the school's hiring system transformed from one dependent on immigrants from the French Caribbean to one

49 The ex-Jesuits in the United States renewed their vows to the Jesuit order in 1805 by joining the group of the Society that continued to exist in White Russia under the protection of the Russian monarchs. After this period, Jesuits began to slowly take control of the school from the CRCC. The full restoration of the order occurred in 1814. See Curran, Bicentennial History, $1: 57-58,64-65$. 
dominated by women slaveowners connected by faith or family connections to the school's priests and students. After 1814, women hired out more than seventy percent of the people enslaved on campus. Female parishioners probably found Georgetown's priests to be reliable business acquaintances. In many cases, women refrained from the practice of using male intermediaries in their business dealings. These women acted independently as owners, arranging for the rental and prices of the people they enslaved. As a group, they created a community of slaveholders who provided a constant supply of labor to the college and who often bankrolled Georgetown's projects by loaning money. ${ }^{50}$

Women from the Fenwick family, for example, leased at least sixteen people in the early nineteenth century, with a man named Phil who died during his time laboring at the school. ${ }^{51}$ One of the most recurring hirers was Margaret Fenwick (176o-1829), the mother of the future bishop of Boston and founder of the College of the Holy Cross, Benedict Fenwick, S.J. (1782-1846). Fenwick rented Georgetown at least six people counted among her property: Michael, Harriet, Gabe, Hillary, and two unnamed men. She also leased to the Jesuits a property that served as a boarding house for students and professors. ${ }^{52}$ Many of these arrangements stood for periods longer than five years. ${ }^{53}$ While boarding at the school, her sons were often charged with "servants and commissions fees," and on one occasion, two of her sons, Benedict and Francis (1785-1825), hired an enslaved people for two days. ${ }^{54}$

During this period, Georgetown also increased its use of enslaved laborers in construction projects. In its early years, the school had used enslaved laborers

50 For women's participation in the slave market see Martin, Divided Mastery, 85; Zaborney, Slaves for Hire, 98-102; Marie S. Molloy, Single, White, Slaveholding Women in the NineteenthCentury American South (Columbia: University of South Carolina Press, 2018); Stephanie E. Jones-Rodgers, They Were Her Property: White Women as Slave Owners in the American South (New Haven, CT: Yale University Press, 2019). For donations and loans by women slave owners, see LA3, 1796-1799 (I.A.i.c), GUA; JC (I.A..2.a) 1808-1813, GUA; Ledger D, 1814-1830 (I.A.i.f.), GUA; WLHL, 1846-1862 (I.AA.i.f), GUA; Brother Sylvester Clarke's Memoranda Book, Miscellaneous Ledgers Box 1 [henceforth BSCMB], GUA; Notes and Bills Receivable, 1841-1892 (I.A.6.h.), GUA.

LB1, 1800-1803 (I.A.i.d.) GUA; LC, 1803-1813 (I.A.i.e); GUA; DBLC, 1803-1808 (I.A.A.b.) GUA; EB, 1802-1808 (I.A.3.b); GUA; JC (I.A..2.a) 1808-1813, GUA.

Ledger D, 1814-1830 (I.A.i.f.), GUA; JC (I.A..2.a) 1808-1813, GUA; LC, 1803-1813 (I.A.i.e), GUA; JD, 1813-1821 (I.A.2.b), GUA; George Fenwick's Day Book, Box 42, Folder 1, MPA. On the Fenwick Family boarding students, see Curran, Bicentennial History, 46; William W. Warner, At Peace with All their Neighbors: Catholics and Catholicism in the National Capital, 1787-1860 (Washington, DC: Georgetown University Press, 1994), 240n44.

53 See JC (I.A..2.a) January 1808-September 1813, GUA; JD, 1813-1821 (I.A.2.b), GUA. BER, 1796-1799 (I.A.4.a). 
for one of its first buildings, Old North. ${ }^{55}$ To expand the college in 1816 , the Jesuits at Georgetown hired people from neighborhood slaveowners who were not part of the college's usual business acquaintances. Prominent slaveowners from the neighborhood provided an enslaved workforce that focused on different aspects of Georgetown's expansion..$^{56}$ Daniel Bussard (d.1830), a land developer and builder who lived steps from campus hired out four of his enslaved masons for the construction of the infirmary and a smokehouse. ${ }^{57}$ George B. Magruder (d.1817), a merchant, tobacco planter, hired out an enslaved man named George along with a group of unnamed men to "lay thirteen thousand bricks," build arches, and chimneys. Georgetown also paid the mayor of the city, John Cox (in office 1823-45), for the labor of a man named Richard and for a group of carpenters whose activities included "laying 254,888 bricks, building a 188-ft fire wall, walling up a well for privy, and building 1 window in servants' room."58

This construction project demonstrated the reliance of the college Jesuits on enslaved labor for the existence of the school. This expansion was a sorely needed enterprise for an institution that had issues boarding students and creating a living space similar to European boarding schools. ${ }^{59}$ Several groups of unnamed men were hired for periods of days. Besides the men enslaved by Cox, Daniel Bussard, and Magruder, Georgetown also hired groups of men from James Harvey (1795-1867) and George Athee (dates unknown). Harvey hired out, for periods of twenty-two days, at least six enslaved men named Edward, Isaac, Ben, Charles, Tobias, and Sam. Some of their activities included the construction of "a vault in the academy," "building ovens in the smokehouse," and hauling stone and sand. Athee received $\$ 181$ for one 103 days' work by Isaac, who was involved in the building of ovens for the infirmary and topping the

55 Before the construction of the infirmary in 1816, there is little information on the use of enslaved laborers to construct Georgetown's oldest buildings. See DB, September 14, 1814-February 5, 1817 (I.A.4.e.), GUA. For the construction costs of Georgetown's first building, see "Construction estimate for Academy," Box 19, Folder 4, MPA; "Estimate of Carpenters work to be done at Geo.town," Box 19, Folder 4, MPA; Curran, Bicentennial History, 1:24.

$5^{6}$ While most of the owners of Georgetown's enslaved community were Catholic, the majority of the owners of the enslaved people who expanded the college were Protestant businessmen. On the posts and dealings of these men, see "Georgetown Journals, 1751-1802," and "Board of Aldermen Journals," Box 1, Reel 1 and 2, Georgetown, Washington, DC. Corporation Government Records, Manuscript Division, Library of Congress, Washington, DC.

57 IL, 1816-1830, Box 1, Folder 1, IC, GUA. On the Bussard residence, see William P. Thompson, "Bussard Newman House-HABS no. DC-196," Historic American Buildings Survey, Office of Archeology and Historic Preservation, National Park Service, June 1968. The relationship between David and Philip Bussard is unknown.

$5^{8}$ IL, 1816-1830, Box 1, Folder 1, GUA.

59 Curran, Bicentennial History, 46, 67. The construction is also mentioned by Fr. John McElroy in his diary. See Diary 1, Vol 2, 1818, Box 1, Folder 2, JMcP. 
chimneys at the church. There was not an aspect of this project in which slavery was not involved. Enslaved people delivered the construction materials, were carriers of notes for their payment, and even delivered the food to maintain the working crews and the college during this expansion. ${ }^{60}$

These enslaved laborers represented a temporary addition to the school's enslaved community, bringing the total of enslaved people at the college close to twenty between 1815 and 1816 . However, the school's expansion along with administrative problems, and the poor management of the plantations held in trust by the CRCC precipitated a crisis at Georgetown that decreased its revenues and labor force. As the 1820 s came to an end, Georgetown had less income flowing from the Jesuit plantations and saw decreasing revenues from their base of slaveholders. The college did not receive fees from parents, even when these fees had been reduced. More than half of the boarders were in debt to the college.${ }^{61}$ Moreover, the barter economy that allowed parents to exchange enslaved labor with school fees had stopped as the majority of the hirers were now widowed women whose children had already graduated. Georgetown's main source of enslaved labor on campus was coming to an end as Maryland's slaveholders considered selling people to "Georgia-men." ${ }^{2}$

The Jesuits who led Georgetown were part of this transformation of Maryland slaveholding. After discussions that began as early as 1810, they initiated a plan to sell the majority of the people they enslaved at their Maryland plantations. ${ }^{63}$ They also explored the possibility of sending them to Liberia. ${ }^{64}$ The arrival of a Jesuit visitor from Rome increased the pressure to divest the slaveholdings of a mission that was known as "the deceased limb of the Society." ${ }^{5}$ Georgetown was the neural point of this plan. The Jesuits used the

6 IL, 1816-183o, Box 1, Folder 1, IC, GUA.

61 Adam Marshal to Francis Neale, January 5, 1821, box 59, Folder 4, MPA; Neale to the Luigi Fortis (1748-1829; in office 1820-29), March 1824, Box 6o, Folder 8, MPA. On Georgetown's financial outlook, see "Report on the Financial Condition of the Province, 1820," Box 6o, Folder 7, MPA; "Relations of students owing Money," Box 19, Folder 5, MPA; Curran, Bicentennial History, 98.

62 The Jesuits also considered selling their enslaved community for a term of years, See Enoch Fenwick (1780-1827) to Francis Neale, May 24, 1816, Box 59, Folder 17, MPA.

63 "Proceedings of the CRCC, May 18-19, 1813," Box 24, Folder 1, MPA; "Proceedings of the CRCC, September 14, 1813," Box 24, Folder 1, MPA; "Proceedings of the CRCC, June 14, 1814," Box 24, Folder 1, MPA; Peter Kenney (1779-1841) to Louis DeBarth (d.1822), April 24, 1820, Box 59, Folder 7 , MPA.

64 Will Erkead (dates unknown) to William McSherry (d.1839), October 17, 1834, Box 13, Folder 4, MPA; Murphy, Jesuit Slaveholding, 193-94.

65 Charles Plowden to Kenney, June 12, 1819, cited in Cornelius Michael Buckey, Stephen Lariguadelle Dubuisson, SJ and the Reform of the American Jesuits (Lanham, MD: University 
school to identify possible buyers. They discussed, lobbied, and wrote about the issue on school grounds. ${ }^{66}$ Georgetown's president, Thomas Mulledy (in office 1829-38), networked within the school's acquaintances in search of a buyer ${ }^{67}$ At least three times, they tried to sell their enslaved community to parents of students enrolled at the school, including the newspaper publisher Duff Green (1791-1875).68

In 1838 , after postponing the sale for a year because of the panic of 1837 , the Jesuits settled on two buyers, the Louisiana politician Henry Johnson (17831864) and Dr. Jesse Batey (d.1852). ${ }^{69}$ A nephew of Johnson would soon enroll at the school..$^{70}$ Part of the principal of the sale directly benefited the coffers of the institution. ${ }^{71}$ Georgetown University was the place where the Jesuits

Press of America, 2013), 94. On the importance of the arrival of the visitor, Fr. Peter Kenney, see Curran, Bicentennial History, 89-90; Curran, "Peter Kenney: Twice Visitor of the Maryland Mission (1819-21, 1830-33) and Father of the First Two American Provinces," in With Eyes and Ears Open: The Role of Visitors in the Society of Jesus, ed. Thomas M. McCoog (Leiden: Brill, 2019), 191-213; Thomas Morrisey, Peter Kenney, S.J., 1779-1841: The Restoration of the Jesuits in Ireland, England, Sicily, and North America (Washington, DC: Catholic University of America Press, 2014), 296-99.

66 Thomas Mulledy to John McElroy, June 12, 1838, Box 66, Folder 5, MPA; Mulledy to McElroy, November 11, 1838, Box 66, Folder 3, MPA; Fidelis Grivel to C.C. Lancaster, November 6, 1838, Box 66, Folder 3, MPA.

67 Mulledy to McElroy, June 12, 1838, Box 66, Folder 5, MPA.

68 Kenney to McElroy, August 19, 1832, Box 63, Folder 18, MPA; Kenney to Francis Neale, September 10, 1832, Box 63, Folder 17, MPA; Duff Green to Joseph Rosati (1789-1847, as bishop of St. Louis, 1826-43, February 7, 1838, Archdiocese of St. Louis Office of Archives and Records, "Duff Green plans to purchase the Maryland Jesuits' slaves and relocate them to Arkansas, February 7, 1838," Georgetown Slavery Archive, http://slaveryarchive.georgetown. edu/items/show/480 [accessed May 30, 2020].

69 At the time of the sale, Johnson was serving in the US House of Representatives. He had previously served as governor of Louisiana (1824-88). On the sale, see Articles of Agreement Between Thomas F. Mulledy of Georgetown, Jesse Batey, and Henry Johnson of the State of Louisiana, June 19, 1838. Box 40, Folder 10, MPA. On the sale of 1838, see Robert Emmett Curran, "Splendid Poverty': Jesuit Slaveholding in Maryland, 1805-1838," in Catholics in the Old South: Essays on Church and Culture, ed. Randall Miller and Jon Wakelyn (Macon, GA: Mercer University Press, 1983), 125-46; Murphy, Jesuit Slaveholding, 187-214; Adam Rothman, "Georgetown University and the Business of Slavery," Washington History 29, no. 2 (Fall 2017): $18-22$.

70 For the terms of the sale, see Jan Roothaan (1785-1853, in office 1829-53) to McSherry, December 27, 1836, Box 93, Folder 9, MPA; Francis Vespre, Provincia di Maryland-Intorno alla vendita di nostri servi, 1836, ARSI, Maryl 5-II 6. On Joseph Johnson's enrollment at Georgetown and the use of remittances from the sale to defray the costs of his tuition, see Vespre to Johnson, March 29, 1840, Letter Book 1, 163, Box 77, AMPA; DCB, 1845-1848 (I.A.3.l), GUA.

71 DCB, 1839-186o, 19oE, Box 68, AMPA; Bill Book 1840-1846 (I.A.6.g), GUA; 191AL, Box 68, AMPA. 
conceived, planned, and executed the sale of 272 people they held in bondage. But the Jesuits did not sell a single individual who labored at their school, since they rented most of them. ${ }^{72}$ At Georgetown, the Jesuits actually bought people to labor on campus at the same time that they orchestrated the mass sale of people from their plantations. ${ }^{73}$

The sale of 272 enslaved people in 1838 did not transform Georgetown's enslaved labor force. From 1840 to 185 o, at least ten enslaved men and two enslaved women labored at the college. ${ }^{74}$ These men cleaned dormitories, cooked for students and priests, took care of Georgetown's president, and cleaned the school during vacations. As the school's properties grew, they toiled in newly constructed vineyards, a college farm, and the Jesuits' vacation villa. ${ }^{75}$ Women labored at the washhouse, cleaning the clothes of over a hundred students and twenty priests. They battled unhygienic conditions that saw some of them ravaged by fevers. ${ }^{76}$ Nearly fifty years after its opening, Georgetown College still ran on the labor of the enslaved.

However, the Jesuits' ways of obtaining enslaved laborers adapted as the number of students who used enslaved people to pay school fees diminished precipitously after 1840. There were two separate reasons for this development. First, there was a concerted effort by the school's bookkeeper, Br. Sylvester Clarke (1820-68), to limit specie payments. ${ }^{77}$ Only families with long histories

72 The actual number of people sold in 1838 remains unclear. Historian Sharon M. Leon notes that "although the articles of agreement specify that 272 people are being sold, the 1838 census document lists 278 people." See Leon, "Re-presenting the Enslaved Community Sold by the Maryland Province Jesuits in 1838," September 30, 2016 (http://www.6floors. org/bracket/2016/o9/30/re-presenting-the-enslaved-community-sold-by-the-marylandprovince-jesuits-in-1838/) [accessed May 30, 2020]. Leon, Jesuit Plantation Project (https:// jesuitplantationproject.org/s/jpp/page/welcome/) [accessed May 30, 2020]. DB, $1830-1836$ (I.A.4.g), GUA.

74 VASWS, 1837-1846 (I.AA.1.h.) GUA.

75 191AL, Box 68, AMPA; WLHL, 1846-1862 (I.AA.i.f), GUA; VASWS, 1837-1846 (I.AA.1.h.) GUA; LF, 1838-1842 (I.A.1.h.), GUA; Ledger G, 1841-1845 (I.A.1.i), GUA; EB, 1841-1845 (I.A.3.k.), GUA.

76 See DB, 1837-1854 (I.A.4.h), GUA; JG, 1838-1875 (I.A.2.e.), GUA; LF., 1838-1842 (I.A.1.h), GUA; CB, 1845-1853 (I.A.3.m.), GUA. For washhouse conditions, see "Infirmary Book, 1840-1857," Box 2, Folder 3, IC, GUA; Consultation of December 9, 1840, Georgetown University's Consultors Books, Box 6, Folder 1, GUA.

77 For enrollment numbers, see Curran, Bicentennial History, 397. 
with the school were allowed to use this mode of payment. ${ }^{78}$ Second, after 1840, Georgetown transitioned from being the school of choice for Maryland's old Catholic families to an institution dominated by students from the Deep South. ${ }^{79}$ With this transformation the number of enslaved laborers available from students decreased substantially, as hiring a person from them would have potentially required importation into the city. The banning of the slave trade in the District of Columbia in 1850 further restricted Georgetown's option of using students to obtain enslaved laborers.

As the number of students who used enslaved people to defray tuition decreased, geography became the determinant factor in Georgetown's hiring market. More than half of the enslavers who rented people to the school lived in the city of Georgetown. Wealthy, well connected residents hired out people to the school for months. For example, Bladen (1810-70) and James Forrest (d.1868), two of the richest men in the city, leased Georgetown three men from 1846 to 1849 . Aaron, Jim, and an unnamed man labored at Georgetown after being rented by the Forrests to labor in dormitories and the grounds. ${ }^{80}$ The Forrests were benefactors of the college, parents of students, and their ties to the Jesuits were such that some family members converted to Catholicism during the period when they rented people to the school. ${ }^{81}$

Women continued to be crucial to the perpetuation of slavery at Georgetown. Arrangements that spanned years were common between the Jesuits and their female business partners. For example, Mary Fenwick (1787-1866) rented out a man named Joseph Edelin to the school for more than ten years. The school's authorities often deferred the payments owed Fenwick for Edelin's labor. In October of 1845, the Jesuits discharged Edelin from campus, paying Fenwick only half of the money owed to her. However, their lack of payment does not appear to have been an obstacle between her and the Jesuits, as two months later, on December 3, 1845, the Jesuits rehired Edelin, this time to labor at the college farm for $\$ 8$ a month. ${ }^{82}$

Another woman with business dealings with the Jesuits was Eliza Jenkins (1787-1859), the aunt of the college's treasurer. Jenkins hired out a man named

78 For enrollment, see Curran, Bicentennial History, 397. For specie payments, see Bill Book, 1840-1846 (I.A.6.g), GUA. On the use of enslaved laborers to pay fees, see Ledger G, 1841-1845 (I.A.1.i.), GUA; VASWS, 1837-1846 (I.A.A.1.h.), GUA; Ledger E, 1830-1838 (I.A.1.g.), GUA.

79 Curran, Bicentennial History, 161.

80 On the Forrests' wealth, see Mary Mitchell, Divided Town (Barre, MA: Barre Publishers: 1968), 27-9, 36; Georgetown, DC City Directory, 1834. For their hires, see VASWS, 1837-1846 (I.A.A.1.h.), GUA; WLHL, 1846-1862 (I.AA.i.f), GUA.

81 Warner, At Peace with All their Neighbors, 200.

82 DCB, 1845-1848 (I.A.3.l.), GUA; VASWS, 1837-1846 (I.A.A.1.h.), GUA. 
Charles Taylor for a number of years to the school. Taylor labored at the college since 1836, at a time when his enslaver was Ralph Semmes (1809-77), a Georgetown resident. ${ }^{83}$ Semmes sold Taylor to Jenkins in 1840 and the new enslavers continued to rent Taylor to the college. In 1842, Jenkins sold Taylor to Georgetown for $\$ 300$, where he remained for many years. ${ }^{84}$ This transaction, along with the sale of a man named Aloysius in 1844 for $\$ 635$ were the only two forays in the slave trade by the school after $1840 .{ }^{85}$

Georgetown's limited incursions in the slave trade, along with the decrease in leases by students, heightened the importance of religious and professional communities as providers of enslaved laborers to the institution. Medical practitioners with long histories with the college rose as an important group of providers of laborers in this period. Such were the cases of Dr. Benjamin Bohrer (d.1862) and Dr. Nicholas Worthington (1788-1849), two men who had provided medical services to the college and who complemented the income from their medical practice with an active participation in the slave trade. ${ }^{86}$ Bohrer hired out to the Jesuits an enslaved man named Salvadore, who labored primarily in the kitchens. ${ }^{87}$ Worthington, on the other hand, was an old acquaintance of the Jesuits. His father, Dr. Charles Worthington (1759-1836), had been the school's doctor during Georgetown's first decades and had often hired out his laborers to the Jesuits. ${ }^{88}$ His son preserved his relationship with the school. From his property in Charles County, Nicholas Worthington purchased an enslaved person as the Jesuits sold the majority of their enslaved community in $1838 .{ }^{89} \mathrm{He}$ also offered his medical services to the school and hired out a man by the name of Frank Butler. ${ }^{90}$

83 EB, 1829-1836 (I.A.3.g.), GUA.

84 See EB, 1841-1845 (I.A.3.k.), GUA; VASWS, 1837-1846 (I.A.A.1.h.); BSCMB, GUA.

85 For Aloysius sale, CB, 1841-1845 (I.A.3.j.), GUA. In this period, the Jesuits also purchased one person in the plantations. See Bill of Sale for Len, September 4, 1843, Box 6, Folder 5 , Maryland Province Collection, Georgetown University; Vespre to Woodley, April 16, 1844, Letter Book 2, Box 77, AMPA.

86 On Bohrer and Worthington's medical services at the College, see EB, 1809-1822 (I.A.3.c.), GUA; Day Book Drs. Bohrer and Magruder, 1835-1836, Box 1, Folder 8, IC, GUA. For Bohrer's practice with the enslaved community of Georgetown's neighborhood, see Medical Visits Bohrer and Magruder, 1831-1832-1833, Box 1, Folder 6, IC, GUA.

87 WLHL, 1846-186o (I.A.A.1.f.), GUA.

88 IL, 1817-1819, Box 1, Folder 1, IC, GUA; LA1, 1789-1793 (I.A.1.a.) GUA; LA3, 1796-1799 (I.A.1.c.), GUA; JC, 1808-1813 (I.A.2.a.), GUA; LB1, 1800-1803 (I.A.1.d.), GUA.

89 DCB, 19oE, Box 68, AMPA.

90 VASWS, $1837-1846$ (I.A.A.1.h.), GUA; WLHL, 1846-186o (I.A.A.1.f.), GUA; DCB, 1845-1848 (I.A.3.l.), GUA. 
Butler labored at the school's kitchens from 1843 to 1848 for an average of $\$ 7$ a month plus clothing, all paid in monthly installments to his enslaver. In 1846, after a change in the school's treasury office, Worthington negotiated an increase of $\$ 2$ a month for the revenue he received from Butler's labor. In exchange for this raise he released the Jesuits of the obligation of furnishing Butler with clothes. ${ }^{91}$ With this new agreement in place, Worthington continued to receive payments for two years, after which the Jesuits cordially informed Worthington that Butler's "services would be dispensed," even if there was not a "a motive or any complaints." ${ }^{2}$ However, Butler's dismissal from the college did not mark the end of his time as a laborer at Georgetown. His stay spanned nearly ten years and outlasted his status as an enslaved person. In July of 1849, Worthington passed away, leaving in his will a provision allowing Butler's family to purchase his freedom for $\$ 200 .{ }^{93}$ Two months after Worthington's death, Frank Butler appears to have registered as a free man with the city, and Br. William Smith (dates unknown) hired him to labor in the dormitories of the college on a salary of $\$ 10$ a month. ${ }^{94}$

Butler's life at the school and his transition from slavery to freedom over the course of his hire at Georgetown reveals the dynamic nature of the school's labor force during the 1840s. The presence of free laborers at the college continued to increase over the years, particularly after 1845 . However, the majority of them were not free people of color. They were Irish men who had recently immigrated into the area. ${ }^{95}$ As the numbers of immigrant laborers increased in cities, the spaces for enslaved laborers and free workmen changed. Once involving all areas of the college, the presence of enslaved men on campus became constrained to student dormitories and the kitchen. ${ }^{96}$

The number of enslaved men fluctuated from a high of eleven at the beginning of the 1840 os to less than five in $185^{\circ}$. In this period, only three enslaved people remained in the college on a yearly basis. Jesuit lay brothers-whose

91 Vespre to Dr. N[icholas] W. Worthington, June 22, 1846, Georgetown Treasurer's Letter Books, 1840-1858, Box 2, GUA.

92 Vespre to Nicholas Worthington, August 31, 1847, Georgetown Treasurer Letter Books, 18471849, Box 2, GUA; DCB, 1845-1848 (I.A.3.l.), GUA.

93 Nicholas Worthington Will, July 16, 1849, Wills, Boxes oo19 D'lagnel, Julian A-o22 Baines, Hanson, 1847-1854, 340-44.

94 WLHL, 1846-186o (I.A.A.1.f.), GUA. Butler's manumission record was registered with the city of Washington according to the financial ledgers of Georgetown University. However, volume $4(1846-55)$ is missing.

95 Multiple accounts show arrival dates from Ireland for the laborers hired by the college, the purchase of postage for letters sent to Ireland, prayer books, and pew rents. For examples, see WLHL, 1846-186o (I.A.A.1.f.), GUA; VASWS, 1837-1846 (I.A.A.1.h.), GUA.

96 DCB, 1845-1848 (I.A.3.l.), GUA; WLHL, 1846-186o (I.A.A.1.f.), GUA. 
numbers had increased over the years-often hired cooks and day laborers for shorter periods of time during the school term, acquiring only temporary relief for their labor needs. This hiring system increased the fluctuation of the school's labor force, particularly in peak times such as the harvest season. ${ }^{97} \mathrm{As}$ the numbers of enslaved men laboring in the college decreased, the number of Irish laborers grew considerably. Irish men labored in the gardens, the priests' dormitories, and the priests' kitchens alongside the French and Italian cooks hired for Georgetown's president. With salaries of \$10 a month, and no obligations concerning meals, health care, and lodgings, they appear to have been a more competitive option to the cost-conscious Jesuits, who decided in 1844 to start decreasing their enslaved labor force. ${ }^{98}$

A crucial factor that precipitated the decline in enslaved laborers at the college was the actions of enslaved men who purchased their freedom. After 1850, as the landscape of slavery changed in the nation's capital, Charles Taylor and James Henry Young followed Frank Butler in purchasing their freedom while they labored at Georgetown. Young began laboring at Georgetown University intermittently since 1843, when his enslaver Mary Bronaugh Hook (1811-96), rented him to the Jesuits, using her brother Jeremiah Bronaugh as an intermediary. ${ }^{99}$ After nearly ten years of labor at Georgetown, by 1852 Young appears to have negotiated his freedom with Hook and Bronaugh. On November 11, $185^{2}$, Georgetown loaned Young $\$ 119.50$ to purchase his freedom as well as his mother's. ${ }^{100}$ In this arrangement, the school advanced Young money for his freedom papers under the condition these "would remain in the possession of Georgetown College's authorities" until he paid off his debt. Young labored as a slave who was actually free under the law for nearly a year, until November 29, 1853, when he settled his debt with the Jesuits and took possession of his papers. Once in possession of his freedom documents, he did not leave the school; he continued to labor cleaning dormitories, having arranged with the president of the college, Bernard Maguire (in office $185^{2-58}$ ), a salary of $\$ 12$

97 See EB, 1841-1845 (I.A.3.k.), GUA; DCB, 1845-1848 (I.A.3.l.), GUA; WLHL, 1846-186o (I.A.A.1.f.), GUA.

98 See DCB, 1845-1848 (I.A.3.l.), GUA; VASWS, 1837-1846 (I.A.A.1.h.), GUA. On the boarding of Irish laborers, see WLHL, 1844-1862 (I.A.A.1.f.); GUA. On foreign cooks for the College president, see EB, 1841-1845 (I.A.3.k.), GUA; WLHL, 1846-186o (I.A.A.1.f.), GUA. VASWS, 1837-1846 (I.A.A.1.h.), GUA; WLHL, 1844-1862 (I.A.A.1.f.); Ledger H, 1845-1849 (I.A.i.j.), GUA; DCB, 1845-1848 (I.A.3.l), GUA.

100 WLHL, 1844-1862 (I.A.A.1.f.), GUA. The reasons for this sale are unclear. One possibility is the fact that Hook was about to move to Texas with her younger brother, Dr. John Mitchel Bronaugh. See J. M. Bronaugh, 186o Federal Census, Census Place: Jackson Texas, Page 369; J. M. Bronaugh, 1870 Federal Census, Census Place: Jackson Texas, Page 476A. 
a month. ${ }^{101}$ He received an extra salary during summer break and used the Jesuits as a bank, usually depositing with them a percentage of his salary as savings. He labored under these conditions for more than a decade. ${ }^{102}$ Young left campus as a free man on the morning of May $5,1864.103$

Young's labor at the college for more than ten years and his transition from slavery to servitude is only surpassed by Charles Taylor's twenty-five years as an enslaved and free man at Georgetown. After Taylor became property of the school in 1842, he continued to labor cleaning dormitories, painting, and occasionally working during the harvest on the college farm. ${ }^{104}$ On March 9, 1853, his financial account registered the payment of freedom papers and an increase in his wages within the college. After seventeen years of laboring under slavery at the school, Taylor became a free man. He remained at the school until his death in 1861, at age forty-one. ${ }^{105}$ Most of his life had been lived under slavery at Georgetown College. ${ }^{106}$

At the time of Taylor's death, only one enslaved person labored at Georgetown, Aaron Edmonson. Edmonson arrived at the school in 1859 as a servant in the student dormitories. Like Young, he had been hired to the school on more than one occasion. ${ }^{107}$ He lugged coal during the winter, painted halls during the summers, and cleaned after students during the school term. ${ }^{108}$ His enslaver was Ann Forrest Green (1797-1870), a prominent

\footnotetext{
101 WLHL, 1844-1862 (I.A.A.1.f.); CB, 1842-1852 (I.A.2.n.), GUA; CB, 1852-185 (I.A.3.o), GUA.

102 WLHL, $1844-1862$ (I.A.A.1.f.); CB, 1856-1858, (I.A.3.p.), GUA; CB, 1859-1865 (I.A.3.q.), GUA.

103 JG, $1838-1875$ (I.A.2.e.), GUA.

104 EB, 1841-1845 (I.A.3.k.), GUA; CB, 1831-1841 (I.A.3.h.), GUA; VASWS, 1837-1846 (I.A.A.1.h.), GUA; DCB, 1845-1848 (I.A.3.l.), GUA.

105 WLHL, 1844-1862 (I.A.A.1.f.); GUA; CB, 1852-1856 (I.A.3.o), GUA; CB, 1856-1858," (I.A.3.p.), GUA; CB, 1859-1865 (I.A.3.q.), GUA; JG, 1838-1875 (I.A.2.e.), GUA; “September, 1861," Holy Trinity Church Deaths, 1818-1867, 109, Digital Georgetown.

106 For important events in Charles Taylor's life, see September 22, 1836-Marriage of Charles Taylor and Mary Boarman, Holy Trinity Church Archives, Sacramental Registers, "Marriages (1806-1871)," 43, Digital Georgetown; March 4, 1838-Baptism Charles Francis Taylor, Holy Trinity Church Archives, Sacramental Registers "Baptisms (1835-1858)," 6o, Digital Georgetown; March 1, 1840-Baptism Theodore Agustin Taylor, Holy Trinity Church Archives, Sacramental Registers, "Baptisms (1835-1858)," 100, Digital Georgetown; "September, 1861," Holy Trinity Church Deaths, 1818-1867, 109, Digital Georgetown.

107 Edmonson's first hire at the school was from May to September of 1849. See WLHL, 18441862 (I.A.A.1.f.), GUA. His whereabouts between 1849 and 1859 are unknown. It is possible that he served as a valet or servant in "Rosedale," Green's renowned house in Georgetown along with other members of his family. JG, $1838-1875$ (I.A.2.e.), GUA.
} 
Catholic woman whose children attended Georgetown College. She had inherited Edmonson and his two sisters from her mother, Rebecca Forrest (1764-1843). She received \$12 a month for Edmonson's labor, which was collected by her son Osceola Green. ${ }^{109}$ Edmonson labored for three years at the school, with a brief interruption between May and June of 1861. During his time at Georgetown, Union troops took over the school, students left to join the Confederacy, and the school's labor force continued to diversify as the establishment of a Union encampment demanded more laborers. Edmonson left the school on March 3, 1862, with one pair of shoes, a suit, and one pair of gloves. ${ }^{110}$

Edmonson achieved his freedom one month later, on April 16, 1862, with the passage of the Compensated Emancipation Act of the District of Columbia. He was thirty years old at the time. On June 28,1862 , Green petitioned the government for a compensation of $\$ 500$ for the loss of his labor. She received \$109.50.111 Although Edmonson labored for years at Georgetown, the archival record recognizes Green as his owner, hiding the ways in which the Jesuits profited from his labor. Five months after Edmonson became free, the Greens continued to profit from his labor, as the school reimbursed them with nearly $\$ 40$ of back wages. Green described Edmonson in her compensation claim as "tall, black, rather straight, very active, and capable."112 He was the last man who labored under slavery at Georgetown College.

109 Ann Forrest Green, The 1861 Diary of Ann (Forrest) Green of Rosedale, ed. James Nicholas Payne (sl: sn, 1991); "Rebecca Forrest Will," 1843, Wills and Probate Records Washington, DC, Boxes oo14, Quinlin, Tasker C-0o18 Degges, John, 1837-1847"; CB, 1859-1865 (I.A.3.q.), GUA; DB, 1859-1864 (I.A.4.i.), GUA. On Osceola Grene's relationship to the college, see Ainsworth R. Spofford, Eminent and Representative Men of Virginia and the District of Columbia of the Nineteenth Century (Madison, WI: Brant \& Fuller, 1893), 161. JG, $1838-1875$ (I.A.2.e.), GUA. On Georgetown during the Civil War, see Curran, The Bicentennial History, 220-48.

111 "Petition of Ann Green, 28 June 1862," Records of the Board of Commissioners for the Emancipation of Slaves in the District of Columbia, 1862-1863, Record Group 217, Records of the United States General Accounting [henceforth RG217]. NARA-DC; Ann Green, Commission's Valuations for Petitions, Records of the Board of Commissioners for the Emancipation of Slaves in the District of Columbia, 1862-1863. NARA Microfilm Publication M520. DB, 1859-1864 (I.A.4.i.), GUA; "Petition of Ann Green, 28 June 1862," RG217, NARA-DC. 
Slavery was one of the defining forces of Georgetown University's history. The school's relationship with slavery and the fruits of enslaved labor was like the many-headed hydra: strong, powerful, and resilient, and enveloping nearly all areas of college life. Enslaved labor was one of the pillars upon which the former Jesuits of Maryland built their academy and the US's first Catholic college. The university's land, its buildings, agents, professors, and founders, as well as many of its students, were entangled with slavery in varying degrees. Revenues derived from slavery filled the college's meager coffers, and its list of creditors and debtors often read as a ranking of Maryland's top planters. The clean clothes the students and priests wore, the buildings they occupied, the classrooms and chapels they filled, the gardens they enjoyed, and the food they ate were all areas touched by slave labor. Georgetown's first seven decades of operation, its growth, the composition of its student body, and its financial management are unexplainable without understanding its relationship with slavery.

Priests, parishioners, and patrons united through the bonds of religion formed the core of Georgetown's slaveholding community. All of the owners who hired enslaved people to the school were related to the institution. More than three quarters of them were parents of students and alumni. The majority of them were women, who were integral to the persistence of slavery on campus. The rest had a legacy of providing services to the Jesuits or were parishioners at Catholic churches. This dynamic put Catholicism at the center of Georgetown's slaveholding world. Hiring enslaved people from their fellow Catholics was a social practice that allowed school leaders to use the education services they provided as a means to acquire the labor they sorely needed.

Slave hiring enabled Georgetown's priests to reap the economic benefits of slaveholding without purchasing people or transferring individuals from their plantations. As a result, the sale of 272 people in 1838 did not change slavery at the school. In fact, the funds from the sale helped strengthen the school's position, benefiting its financial footing, and increasing its demand for enslaved laborers. After the sale of 1838, Georgetown became the center of the Jesuits' participation in the slave trade. In America's first Catholic college, enslavement persisted for decades, connecting the school over the years to faraway places in the Caribbean and to closer locations, such as its community in the District of Columbia.

Georgetown University was an active participant in the slave trade for nearly seventy years. Its choice to hire enslaved people was an economic 
decision that fit its leaders' attitudes towards manual labor as well as the precarious financial standing of the school. Hiring gave the school financial flexibility, allowing it to operate with lower costs. Georgetown hired, bartered, bought, and sold enslaved people since its first years. Its involvement with slavery began when it opened its doors and no history of the college can be complete without recognizing the presence and labor of enslaved people on campus. Byrne, Suckey, Joseph, Nat, Stephen, Tempey, Lewis, Sam, Polly, Sucky, Nicolas, Wat, Harriet, Michael, Gabe, Hillary, Joseph, Frank Butler, James Henry Young, Charles Taylor, and many more whose names are lost to us are already in the College's financial records. It is time for them to be part of Georgetown's history as well. 